\title{
THE IMPACT OF BRAND EQUITY TO PURCHASE INTENTION (CASE STUDY FROM IPHONE USERS IN MAKASSAR)
}

\author{
Gita Gabriella ${ }^{1}$, Sonny ${ }^{2 *}$ \\ ${ }^{1}$ Faculty of business, President university, Cikarang \\ Email : gitagabriella6@gmail.com \\ ${ }^{2}$ Faculty of business, President university, Cikarang \\ Email : sonny@president.ac.id \\ *penulis korespondensi
}

\begin{abstract}
ABSTRAK
Penelitian ini dilatarbelakangi oleh meningkatnya persaingan di pasar ponsel cerdas. Terlepas dari popularitas iPhone ketika perusahaan memperkenalkan iPhone untuk pertama kalinya pada tahun 2007, iPhone telah mengalami persaingan ketat dari produsen smartphone lainnya. Penelitian ini bertujuan untuk mengetahui pengaruh ekuitas merek dan kepuasan pelanggan terhadap niat beli konsumen produk iPhone. Elemen ekuitas merek yang digunakan dalam penelitian ini adalah kesadaran merek, kualitas persepsi, kepuasan pelanggan, dan loyalitas merek. Penelitian ini dilakukan dengan menyebarkan kuesioner kepada sembilan puluh enam responden dengan menggunakan purposive sampling. Responden adalah orang yang saat ini menggunakan produk iPhone. Data dianalisis dengan menggunakan analisis kuantitatif. Analisis kuantitatif terdiri dari uji validitas dan reliabilitas, uji asumsi klasik, analisis regresi berganda, pengujian hipotesis dengan uji $\mathrm{F}$ dan uji $\mathrm{t}$, serta analisis koefisien determinasi (R). Dari hasil penelitian dapat disimpulkan, bahwa kepuasan pelanggan dan loyalitas merek merupakan elemen utama konsumen membeli merek iphone. Sedangkan kesadaran merek dan kualitas persepsi tidak berpengaruh dalam faktor pembelian.
\end{abstract}

Kata kunci : Kesadaran Merek, Kualitas Persepsi, Loyalitas Merek, Kepuasan Pelanggan

\section{ABSTRACT}

This research is motivated by the increasing competition in the smartphone market. Despite the popularity of the iPhone when the company introduced the iPhone for the first time in 2007, the iPhone has experienced stiff competition from other smartphone manufacturers. This study aims to determine the effect of brand equity and customer satisfaction on consumer purchase intentions of iPhone products. The elements of brand equity used in this study are brand awareness, perceived quality, customer satisfaction, and brand loyalty. This research was conducted by distributing questionnaires to ninety-six respondents using purposive sampling. Respondents are people who currently use iPhone products. Data were analyzed using quantitative analysis. Quantitative analysis consists of validity and reliability tests, classical assumption tests, multiple regression analysis, hypothesis testing with the $F$ test and $t$ test, and analysis of the coefficient of determination $(R)$. The results of research can be concluded that customer satisfaction and brand loyalty are the main elements of consumers buying the iPhone brand. Meanwhile, brand awareness and perceived quality has no effect on purchasing factors.

Keywords : Brand Awareness, Perceived Quality, Brand Loyalty, Customer Satisfaction

\section{INTRODUCTION \\ Background}

Based on survey from Statscounter on March 2020, the iPhone itself is only ranked 5th in Indonesia, with a market share of $7.16 \%$. Although the target market is small, there are something that not owned by the four players above the iPhone, namely brand loyalty and prestige. If usually, the lower class players will use lower prices to be able to compete with players above, the iPhone is actually upside down. iPhone uses a premium price, far higher than smartphones in its class. Only certain people can afford it. It can be seen, the strength of prestige far exceeds the power of low prices. Based on this phenomenon, according to Temporal and Trott (2012: 47), to make a brand successful, it must exist a total shift towards customers and 
customers is the sole focus for brand initiatives. The iPhone's brand has focused to customers and being able to build loyalty, even though it is sold at a premium price.

According to Keller (2003), brand will help consumers to recognize a firm's products or services and makes itself distinguish from other competitors. Based on research conducted by Adrian \& Christina (2017) measured brand equity on consumer purchase intention, the results show that brand loyalty plays an important role. In this research, the prestige analyzed conceptually with brand equity will examine how deeply this concept plays a role in purchasing iPhone products.

\section{Problem Identification}

Brand loyalty is essential for a company to have. Previous studies done on brand loyalty have shown that the cost to attract a new customer is five times more expensive than maintain loyal customer. In other words, the higher brand loyalty, the less it costs. In telecommunication industry, especially in smartphone industry which has gain popularity in the last several years where there are tight competitions among smartphone manufacturers, brand is important. The iPhones' manufacturer still has strong loyalty of its customer which may enable repeat purchase. According to study conducted by Consumer Intelligence Research Partner (CIRP), Iphone customers' brand loyalty is 81 percent. This high percentage with current customers is one of the reason Iphone's customers keep buying Iphone's products despite the price.

This research is conducted to discover brand equity's value and customer satisfaction towards consumer purchase intention on iPhone product. Specifically, it can be seen on research objective below.

\section{Research Objective}

a. To understand and identify brand awareness influence towards purchase intention.

b. To understand and identify perceived quality towards consumer purchase intention

c. To understand and identify brand loyalty towards consumer purchase intention.

d. To understand and identify customer satisfaction towards consumer purchase intention.

e. To understand and identify brand awareness, perceived quality, brand loyalty and customer satisfaction towards consumer purchase intention.

\section{Research Limitation}

The scope of the study are ninety six millenial respondents aged 17-30 years old, currently users of iPhone, and stayed in Makassar

\section{Brand Awareness}

Brand awareness is one of important factors in branding and is widely accepted as an essential first step in building a brand. Brand awareness can be defined as the level of which the consumer recognizes the existence or the availability of certain company's products or services.

\section{Perceived Quality}

Keller (2003) defined perceived quality as “customers' perceptions of the overall quality or superiority of a product or service relative to relevant alternatives and with respect to its intended purpose". Zeithaml (1988) referred to the concept as perceived value and has four dimensions, which are: (1) value is low price, (2) value is the quality received for the price paid, (3) value is everything obtained from an offering compared to everything given, and (4) value is whatever is desired in an offering. Aaker (1966) also suggested that perceived quality is the measure of the quality of a brand. Furthermore, Armstrong and Kotler (2003) stated that perceived quality has a direct impact on customer purchase decision and brand loyalty, especially when the consumers 
only has little or no information relating to the product they are going to purchase (Armstrong and Kotler, 2003).

\section{Brand Loyalty}

Brand loyalty is explained as the way to measure the current number of customers of the particular brand (Jensen, 2011). Brand loyalty could also explain as the implied promise to repurchase certain merchandise $(\mathrm{Ou}$, Shih, Chen, \& Wang, 2011). In other words, brand loyalty is not meant as a one time purchase but as a continual purchase.It is suggested that brand loyalty can be increased by building strong customer relationship and increase the quality of consumer loyalty programs which in the end would increase consumer motivation towards purchasing behavior. Brand loyalty could also seen as a consumer preference on particular brand based from previous experience with a product.

Loyalty comes as a result of consumer satisfaction. Most consumers who is satisfied with product quality or product function will show loyalty towards that particular brands and if its loyalty is high then the consumer would become less price insensitive and would show strong interest to purchase other product regardless of the price. Although brand loyalty could be measured from repurchase rate, purchase frequency is not equal to loyalty. This is because behavior loyalty and loyalty attitude represents different things. While behavior loyalty represents repurchase behavior, emotionally loyal means psychological commitment to a brand (Oliver, 1999). In addition, behavioral loyal consumer might act loyal with particular brand but do not have any particular emotional attachment with brand. In other hand, emotionally loyal consumers have deep attachment with the brand and do maximum effort in order to maintain the attachment (Reichheld, 2003).

\section{Customer Satisfaction}

Customer satisfaction is a critical issue in the success of any business system, traditional or online (Ho \& Wu 1999). In order to sustain a growth and market share, companies need to understand how to satisfy customers (Patterson et al. 1997). It is argued that the key to measure user satisfaction is the relationship between satisfaction and service quality (Pitt et al., 1995).

Those who buy the goods or services provided by companies are customers. In other words, a customer is a stakeholder of an organization who provides payment in exchange for the offer provided to him by the organization with the aim of fulfilling a need and to maximise satisfaction. Sometimes the term customer and consumer are confusing. A customer can be a consumer, but a consumer may not necessarily be a customer. Another author explained this difference as a customer is the person who does the buying of the products and the consumer is the person who ultimately consumes the product (Solomon, 2009, p. 34.)

When a consumer/customer is contented with either the product or services it is termed satisfaction. Satisfaction can also be a person's feelings of pleasure or disappointment that results from comparing a product's perceived performance or outcome with their expectations (Kotler \& Keller, 2009, p. 789).

\section{RESEARCH METHODOLOGY Respondent General Overview}

Respondent in this research is people who used iPhone at the present. Respondent is asked to answer questionnaire with demographic questions regarding respondents' data, as well as questionnaire response regarding variable indicators in this research. The response is rated by respondent with likert scale (1-5). There are 96 total respondents, where they first asked to fill 
their identity which covers gender, age and occupation. The detail can be checked on the table below

Table 1. Respondent general overview

Source : Questionnaire, 2019

\begin{tabular}{ccc}
\hline Demographics & Total & Percentage \\
\hline Gender & & \\
Male & 50 & $52,08 \%$ \\
Female & 46 & $47,92 \%$ \\
\hline
\end{tabular}

Age

\begin{tabular}{|ccc|}
\hline 17-25 years old & 67 & $69,79 \%$ \\
25-30 years old & 29 & $30,21 \%$ \\
\hline Occupation & & \\
\hline Student & 34 & $35,42 \%$ \\
Private sector & 26 & $27,08 \%$ \\
Entrepreneur & 36 & $37,50 \%$ \\
\hline
\end{tabular}

\section{RESULT \& DISCUSSION}

\section{Validity Test}

Validity test is done by comparing the value of calculated $r$ value with $r$ table for degree of freedom $(\mathrm{df})$. Since, $\mathrm{df}=\mathrm{n}-2$, where $\mathrm{n}$ is total respondents, $\mathrm{df}=96-2=94$ and alpha $=0.001, \mathrm{r}$ table $=0.33$ (by using $\mathrm{r}$ table on both side). The indicator or question is stated valid if calculated $\mathrm{r}>\mathrm{r}$ table and vice versa.

\section{Answer frequency for each variable}

Scoring technique used in this research is by using Likert scale, where 1 is a minimum score and 5 is a maximum score.

Table 2. Answer Frequency for Each Variable Source : Questionnaire, 2019

\begin{tabular}{|c|c|c|}
\hline Variable & Indicator & Mean \\
\hline & Brand awareness & \\
\hline $\mathrm{X} 1.1$ & Consumer ability to recall Iphone brand & 4,14 \\
\hline $\mathrm{X} 1.2$ & $\begin{array}{l}\text { Consumer ability to recognize Iphone } \\
\text { brand }\end{array}$ & 3,87 \\
\hline $\mathrm{X} 1.3$ & $\begin{array}{l}\text { Consumer ability to recognize Iphone } \\
\text { logo }\end{array}$ & 3,74 \\
\hline & Perceived quality & \\
\hline $\mathrm{X} 2.1$ & The quality of Iphone product & 4,22 \\
\hline $\mathrm{X} 2.2$ & The durability of Iphone product & 4,09 \\
\hline $\mathrm{X} 2.3$ & Brand reputation for quality & 4,5 \\
\hline
\end{tabular}




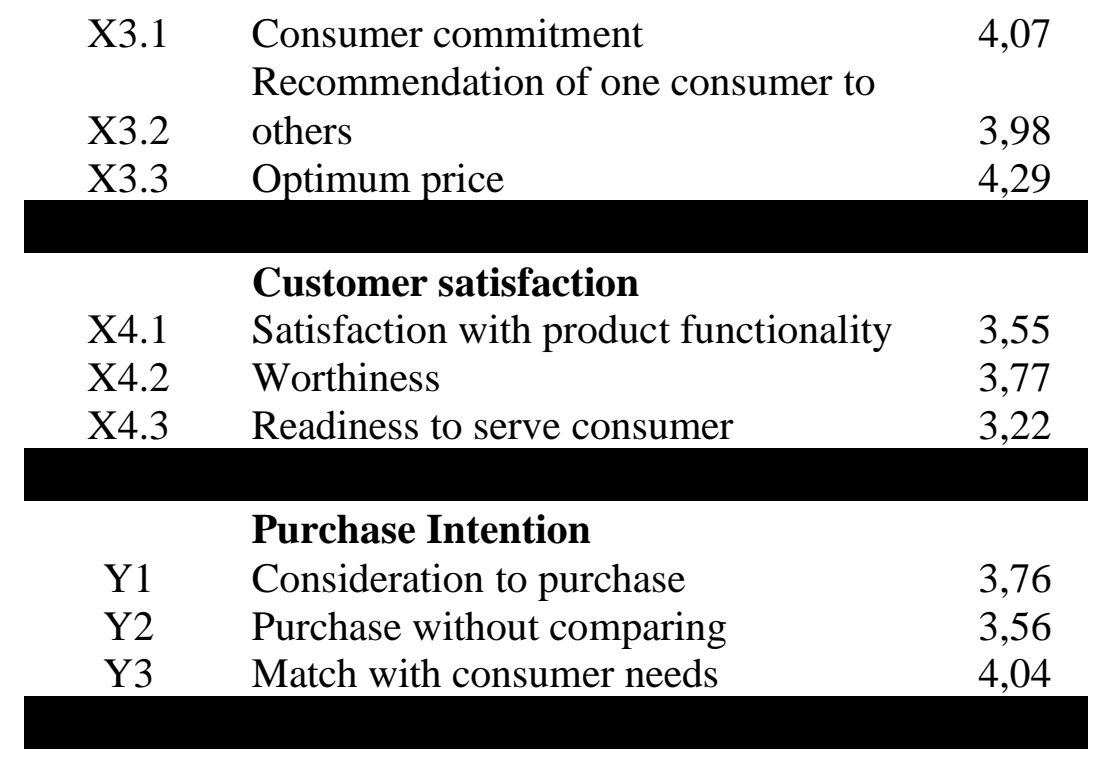

\section{Reliability Test}

Cronbach alpha used on the reliability test. A variable is reliable if Cronbach alpha coefficient 0.60 (Nunnally, 1967).

Table 3. Variable Reliability Test Table

Source : Questionnaire, 2019

\begin{tabular}{|l|l|l|l|l|}
\hline & $\begin{array}{l}\text { Cronbach } \\
\text { Alpha value }\end{array}$ & $\approx$ & 0.60 & Conclusion \\
\hline $\begin{array}{l}\text { Variable } \\
\left(X_{1}\right)\end{array}$ & 0.618 & $>$ & 0.60 & Reliable \\
\hline $\begin{array}{l}\text { Perceived Quality } \\
\left(X_{2}\right)\end{array}$ & 0.675 & $>$ & 0.60 & Reliable \\
\hline $\begin{array}{l}\text { Brand Loyalty } \\
\left(X_{3}\right)\end{array}$ & 0.637 & $>$ & 0.60 & Reliable \\
\hline $\begin{array}{l}\text { Customer } \\
\text { Satisfaction }\left(X_{4}\right)\end{array}$ & 0.849 & $>$ & 0.60 & Reliable \\
\hline $\begin{array}{l}\text { Purchase Intention } \\
(Y)\end{array}$ & 0.781 & $>$ & 0.60 & Reliable \\
\hline
\end{tabular}

Based on Table 3, all the indicators in both dependent and independent variable have cronbach alpha value bigger than 0.60 . Therefore, it can be concluded that all the indicators are reliable.

\section{Normality Test}

Graphic analysis uses histogram, where normality is determined by graphic pattern of the histogram. Regression model fulfill normality assumption when normal probability plot graphic show dots - which represent real data - disperse in the diagonal area and follow the diagonal line. 


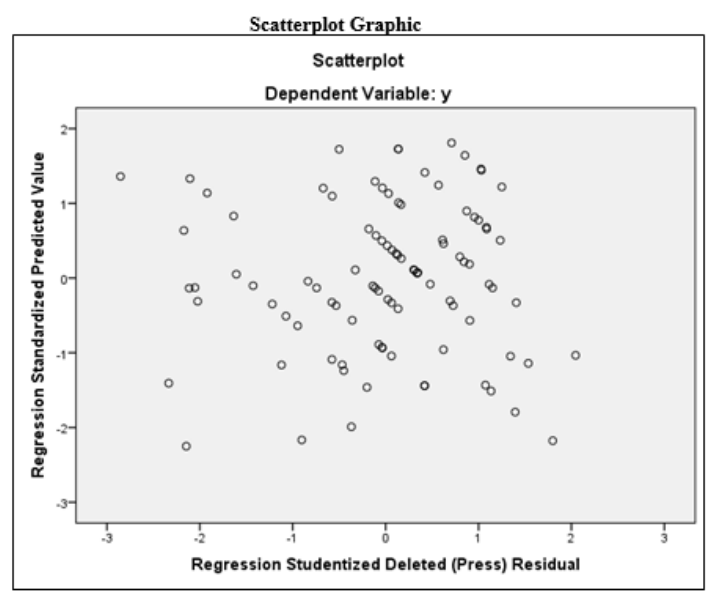

Source : Primary Data by SPSS

Figure 1. Normality Test

Source : primary data by spss

Figure 1 shows that dots - which represents real data - has distributed around the diagonal line, and has also follow the diagonal line. This shows that regression model fulfilled normality assumptions.

\section{Multiple Collinearity Test}

Multiple colliniearity test is used to determine whether there is a correlation between independent variables in the regression model.

Table 4. Tolerance and VIF value table

Source : Questionnaire, 2019

Coefficients

\begin{tabular}{|c|c|c|c|c|c|c|c|}
\hline \multirow[t]{2}{*}{ Model } & \multicolumn{2}{|c|}{$\begin{array}{l}\text { Unstandardized } \\
\text { Coefficients }\end{array}$} & \multirow{2}{*}{$\begin{array}{c}\begin{array}{c}\text { Standardized } \\
\text { Coefficients }\end{array} \\
\text { Beta }\end{array}$} & \multirow[t]{2}{*}{$\mathrm{t}$} & \multirow[t]{2}{*}{ Sig. } & \multicolumn{2}{|c|}{ Collinearity Statistics } \\
\hline & $\mathrm{B}$ & Std. Error & & & & Tolerance & VIF \\
\hline 1 (Constant) & .862 & 1.606 & & .537 & .593 & & \\
\hline Brand Awareness & .119 & .125 & .089 & .950 & .345 & .686 & 1.458 \\
\hline Perceived Quality & .213 & .141 & .155 & 1.514 & .133 & .581 & 1.720 \\
\hline Brand Loyalty & .280 & .123 & .226 & 2.279 & .025 & .620 & 1.612 \\
\hline $\begin{array}{l}\text { Customer } \\
\text { Satisfaction }\end{array}$ & .276 & .072 & .364 & 3.805 & .000 & .665 & 1.503 \\
\hline
\end{tabular}

Table 4 shows that there are no independent variable that have tolerance value less than 0.10 (Tolerance $>0.10$ ), which means that there are no correlation between independent variable that has a value over $95 \%$. The result of VIF value also shows the same thing. There are no independent variable that have VIF value more than 10 (VIF < 10). Therefore, it can be concluded that there are no multiple collinierity among independent variables in this research regression model.

\section{Heteroskedasticity Test}

In this research, scatterplot graphic is used to determine whether there are heteroskedasticity or not. In the scatterplot graphic, if there is certain pattern, like existing dots form specific ordered pattern (fluctuates, widened then narrowed), then there is a heteroskedasticity. 


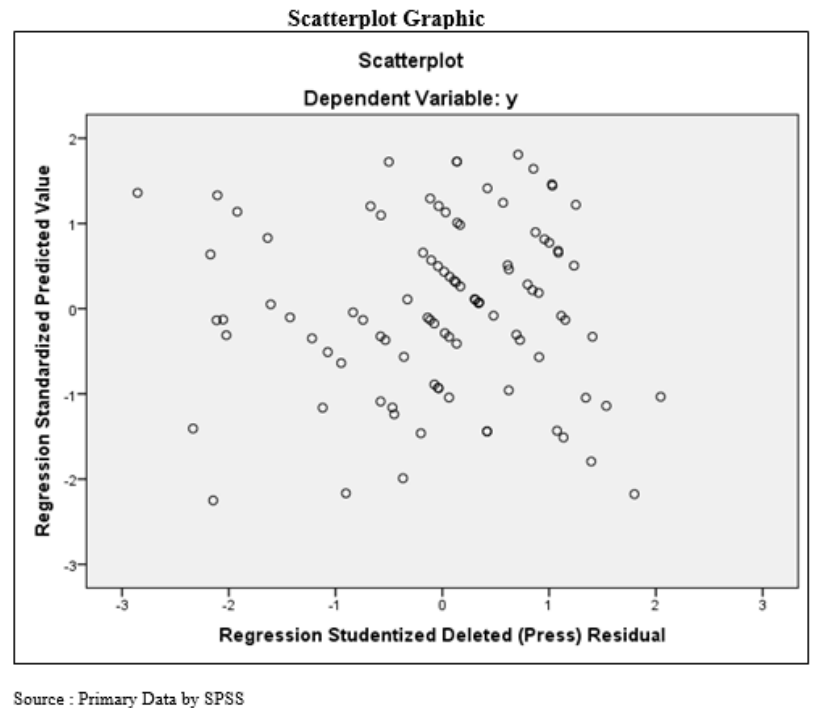

Figure 2. Heteroskedasticity Test

Source : primary data by SPSS

\section{Multiple Regression Analysis}

This research has more than two variable (four independent variables), then regression used in this research is called multiple regression. Multiple regression analysis purpose is to discover independent variables influence (brand awareness, perceived quality, brand loyalty and consumer satisfaction) towards dependent variable (consumer purchase intention).

From above regression equation, it can be concluded that the coefficient from the regression equation is positive. However, due to the result of $\mathrm{t}$ test and $\mathrm{F}$ test from the chapter before, brand awareness variable and perceived quality are not used. Both of variables are not significant and do not have influences towards purchase intention.

1. Independent variable of Brand Loyalty (has a positive influence towards dependent variable of Consumer Purchase Intention ( ) with coefficient value of 0.226.

2. Independent variable of Customer Satisfaction ( ) has a positive influence towards dependent variable of Consumer Purchase Intention ( ) with coefficient value of 0.364 .

\section{Model Testing}

\section{Coefficient of Determination Test}

Coefficient of determination used is Adjusted value due to its reliability in evaluating regression model. This test would result in standard error of estimate (SEE) where the smaller the SEE, regression equation would be more precise in predicting dependent variable.

Tabel 5. Coefficient of determination test table

Source : Questionnaire, 2019

Model Summary

\begin{tabular}{|l|r|r|r|r|}
\hline Model & R & R Square & \multicolumn{1}{|c|}{$\begin{array}{c}\text { Adjusted R } \\
\text { Square }\end{array}$} & $\begin{array}{c}\text { Std. Error of the } \\
\text { Estimate }\end{array}$ \\
\hline 1 & $.669^{\mathrm{a}}$ & .447 & .423 & 1.59409 \\
\hline
\end{tabular}

a. predictors : (constant), $\mathrm{x} 4, \mathrm{x} 1, \mathrm{x} 3, \mathrm{x} 2$

b. dependent variable : $y$ 
According to coefficient of determination test table above, adjusted $\mathrm{R}$ square shows value of 0.423 or $42.3 \%$. This shows that $42.3 \%$ consumer purchase intention can be explained by the variations of the four independent variable (brand awareness, perceived quality, brand loyalty and customer satisfaction).

However, this table also shows that most of the consumer purchase intention $(57.7 \%)$ is explained by factors outside the model. The value of standard error of estimate (SEE) above is 1.59409. The smaller the value of SEE, the more accurate the regression equation in predicting dependent variable.

\section{F-test Statistic}

This test is done by comparing calculated $\mathrm{F}$ value with $\mathrm{F}$ table value by using significant level of $5 \%$. Independent variables have simultaneous influence over dependent variable if calculated $\mathrm{F}$ value is bigger than $\mathrm{F}$ table. Another way is by observing probability value. Independent variables have simultaneous influence over dependent variable if probability value is smaller than 0.05 . However, if probability value is bigger than 0.05 , then independent variable have no simultaneous influence over dependent variable.

Tabel 6. F-test statistic

Source : Questionnaire, 2019

\begin{tabular}{|c|c|c|c|c|c|c|}
\hline \multicolumn{7}{|c|}{ ANOVA $^{\mathrm{a}}$} \\
\hline & & Sum of Squares & $\mathrm{Df}$ & Mean Square & $\mathrm{F}$ & Sig. \\
\hline \multirow{3}{*}{1} & Regression & 186.998 & 4 & 46.749 & 18.397 & $.000^{\mathrm{b}}$ \\
\hline & Residual & 231.242 & 91 & 2.541 & & \\
\hline & Total & 418.240 & 95 & & & \\
\hline
\end{tabular}

a. Dependent variable : y

b. Predictors : (constant), x4, x1, x3, x2

Table 6 shows that the level of significant is 0.000 which is smaller than 0.05 . Therefore, it can be assumed that all the independent variable has simultaneous influence over dependent variable.

\section{T-test Statistic}

$\mathrm{T}$ - test statistic shows how far independent variable influence in individual (partial) in explaining dependent variables (Ghozali, 2005). The result of $\mathrm{t}-$ test statistic is :

1. Calculated $t$ value on Brand Awareness variable (X1) is 0.950 with significant level of 0.345 . Calculated $t$ value is $0.950<1.66$ and significant level of $0.345>0.05$. Therefore, both Ha and Ho is rejected and do not significant with purchase intention.

2. Calculated $t$ value on Perceived Quality variable (X2) is 1.514 with significant level of 0.133 . Calculated $t$ value is $1,514<1.66$ and significant level of $0.133>0.05$. Therefore, both Ha and Ho is rejected and do not significant with purchase intention.

3. Calculated t value on Brand Loyalty variable (X3) is 2.279 with significant level of 0.025 . Calculated t value is $2.279>1.66$ and significant level is $0.025<0.05$. Therefore, $\mathrm{Ho}$ is rejected and $\mathrm{Ha}$ is accepted. This means that brand loyalty in individual has positive influence and significant towards purchase intention.

4. Calculated t value on Customer Satisfaction variable (X4) is 3.805 with significant level of 0.000 . Calculated t value is $3.805>1.66$ and signifact level is $0.000<0.05$. Therefore, 
Ho is rejected and Ha is accepted. This means that customer satisfaction in individual has positive influence and significant towards purchase intention.

\section{Interpretation of results \\ Brand Awareness}

According to the $\mathrm{F}$ test and $\mathrm{T}$ test regarding the significance of brand awareness variable in individual towards purchase intention, it is found that brand awareness does not have any significance and influence towards purchase intention. From beta of standardized coefficient, it could be seen that brand awareness has the least effect (0.089) towards purchase intention.

\section{Perceived Quality}

According to the $\mathrm{F}$ test and $\mathrm{T}$ test regarding the significance of perceived quality variable in individual towards purchase intention, it is found that brand awareness does not have any significance and influence towards purchase intention. Furthermore, from beta of standardized coefficient, it could be seen that perceived quality has the third most effect $(0.155)$ towards purchase intention.

\section{Brand Loyalty}

According to the $\mathrm{F}$ test and $\mathrm{T}$ test regarding the significance of brand awareness variable in individual towards purchase intention, it is found that brand loyalty has any significance and positive influence towards purchase intention. Furthermore, from beta of standardized coefficient, it could be seen that brand loyalty has the second most effect (0.226) towards purchase intention.

\section{Customer Satisfaction}

According to the $\mathrm{F}$ test and $\mathrm{T}$ test regarding the significance of customer satisfaction variable in individual towards purchase intention, it is found that customer satisfaction has significance and positive influence towards purchase intention. Furthermore, from beta of standardized coefficient, it could be seen that brand awareness has the most effect $(0.364)$ towards purchase intention.

\section{Purchase Intention}

Based on $t$ test and $F$ test that was done on all the independent variable to discover the significance and influence over purchase intention, it is found that there are only two independent variables that have an effect towards purchase intention. Based on t test and $\mathrm{F}$ test, only brand loyalty and customer satisfaction is significant and has positive influence towards purchase intention.

\section{CONCLUSION \& RECOMMENDATION Conclusion}

1. Analysis from multiple regression resulted in brand awareness as the forth variable that have an influence towards consumer purchase intention. Despite the theories that argued that high brand awareness will result in high purchase intention, since Iphone only has an average brand awareness, it does not have a strong influence towards consumer purchase intention.

2. Analysis from multiple regression resulted in perceived quality as the third variable that have strong influence towards consumer purchase intention. This result implied that iPhone users purchase intention can be influenced by overall quality perceptions. Good perceived quality would result in high purchase intention. 
3. Analysis from multiple regression resulted in brand loyalty as the second variable which have strong influence towards consumer purchase intention. This strengthened the theory that strong consumers' brand loyalty will result in high purchase intention.

4. Analysis from multiple regression resulted in consumer satisfaction as the variable that have the strongest influence towards consumer purchase intention. It proves that iPhone users purchase intention is affected by their previous experience and satisfaction with Iphone. Higher consumer satisfaction will likely result in higher purchase intention.

\section{Recommendation}

1. Iphone needs to increase its effort in increasing its brand awareness which is also one of the basic important factors. The efforts that Iphone can try in increasing its brand awareness is by creating a unique packaging, or creating a jingle or slogan, so it can capture potential consumers attention fasters. Unique jingle or slogan would also help consumers to remember Iphone brand every time that unique jingle is played. Therefore, it could help Iphone brand into consumers Top of Mind.

2. Iphone needs to increase its product perceived quality. Good perceived quality could help convinced consumer in purchasing the products. Positive perceived quality have several benefits for company like creating clear positioning and create the probability in brand extensions. Perceived quality is not limited to the operating system of iPhone, but also the hardware functionality. Iphone could improve the design of iPhone or add another gadget that could be paired with iPhone.

3. Iphone needs to focus its marketing strategy in maintaining or improve its brand loyalty. As suggested by many theories, high brand loyalty would result in high purchase intention. Moreover, purchase intention is argued to be a tool to determine the probability of consumer purchase action. Iphone can maintain its consumer brand loyalty by creating membership of iPhone users where the member get special offers for certain product purchase. Iphone could also creating an event like birthday, Christmas, etc. where member would get special limited gifts.

\section{REFERENCE}

Aaker, D. (1991). Managing Brand Equity : Capitalizing on The Value of a Brand Name. New York: The Free Press

Adrián Trillo Trillo, C. C. (2017). Measuring Brand Equity in the Smartphone industry: An approach through Aaker's Model. A coruna, Spain: Faculty of Economics and Business of University of A Coruña.

Belleau, B. D. (2007). Purchase intention of young consumers. Clothing and textile research journal, 25.

Blackwell, R. M. (2001). Consumer behaviour. Harcourt College publishers.

Bloemer, J. M. (1989). The illusion of consumer satisfaction. Journal of consumer satisfaction, dissatisfaction and complaining behaviour, 43-48.

Bloemer, J. M. (1994). The impact of satisfaction on brand loyalty : urging on classifying satisfaction and brand loyalty. Journal of consumer satisfaction, dissatisfaction and consumer behaviour, vol. 7, 152.

Chen, C. Y. (2008). Assessing the quality of a web-based learning system for nurses. Journal of medical system 33 (4), 317-325.

Fen, Y. S. (2009). Service quality and customer satisfaction : antecedents of customer's repatronage intentions. . Sunway academic journal no. 4, 59-73. 
Ghozali, I. (2005). Aplikasi analisis multivariate dengan program SPSS. Semarang: Badan penerbit Universitas Diponegoro.

Jalilvand, M. R. (2011). The effect of brand equity components of purchase intentions. International journal of service industry management.

Jensen, J. M. (2011). An empirical examination of brand loyalty. Journal of consumer marketing.

Keller, K. L. (2003). Strategic Brand Management: Building, Measuring, and Managing Brand Equity, 4th edition. New York: Pearson.

Khan, I. G. (2012). Impact of brand related attributes on purchase intention of customers : A study about customers on Punjab, Pakistan. Interdisciplinary journal of contemporary research in business., Vol. 4 no. 3.

Lekprayura, S. (2013). Brand equity and factors affecting consumer's purchase intention towards luxury brands in Bangkok Metropolitan Area. World academy of science, engineering and technology. Bangkok.

Lovelock, C. W. (2005). Service marketing in Asia. New York: Prentice Hall.

Malik, P. D. (2013). Importance of brand awareness and brand loyalty in assessing purchasing intention of consumer. International journal of business and social sciences.

Nam, J. E. (2011). Brand equity, brand loyalty and consumer satisfaction. Annals of tourism research, vol. 38, 1009 - 1030.

Statcounter Globalstats. (2020). Retrieved from Mobile Vendor Market Share in Indonesia August 2020: https://gs.statcounter.com/vendor-market-share/mobile/indonesia

Suddin, L. G. (2009). Predicting intention to choose Halal products using theory of reasoned action. Journal of islamicand middle eastern financial and management, 66 - 76.

Tariq, M. I. (2013). Customer perceptions about branding and purchase intention : A study of FMCG in an emerging market. Journal of basic and applied scientific research, 340 - 347.

Trott, P. T. (2012). Memaksimalkan nilai merek melalui customer relationship management. Jakarta: Salemba empat. 